Christopher A. Muhando, Baraka L. Kuguru, Gregory M. Wagner, Nsajigwa E. Mbije and Marcus C. Ohman \title{
Corallimorpharians in Tanzania
}

Environmental Effects on the Distribution of

\begin{abstract}
This study examined the distribution and abundance of corallimorpharians (Cnidaria, Anthozoa) in Tanzania in relation to different aspects of the coral reef environment. Five reefs under varying degrees of human disturbance were investigated using the line intercept transect and point technique. Corallimorpharian growth and the composition of the substratum were quantified in different habitats within reefs: the inner and middle reef flat, the reef crest, and at the 2 and $4 \mathrm{~m}$ depths on the reef slope. Corallimorpharians occurred on all the reefs and 5 species were identified: Rhodactis rhodostoma, $R$. mussoides, Ricordea yuma, Actinodiscus unguja and A. nummiforme. R. rhodostoma was the dominant corallimorpharian at all sites. Within reefs, they had the highest densities in the shallow habitats. While $R$. rhodostoma occurred in all habitats, the other corallimorpharian species showed uneven distributions. Corallimorpharians ranked second, after scleractinian coral, in percent living cover. Results from this study suggested that corallimorpharians benefited from disturbance compared with other sessile organisms. They preferred inhabiting areas with dead coral, rock and rubble whilst live coral was avoided. There was a positive relationship between percent cover of corallimorpharians and water turbidity and they dominated the more disturbed reefs, Le. reefs that were affected by higher nutrient loads and fishing.
\end{abstract}

\section{INTRODUCTION}

Corallimorpharians (Cnidaria, Anthozoa) are coral-like anthozoans that resemble actiniarian sea anemones in that they do not have a calcareous skeleton (I). However, they are more similar to scleractinian corals in most other aspects of their morphology. Corallimorpharians lack basilar muscles, may have tissue connections between adult polyps, lack ciliated tracts on their mesenterial filaments, and have cnidae that are similar to those of corals (1-4). They are present in most coral reef areas of the world and appear alone or in colonies, and are able to cover large parts of a reef (I, 3, 5-10). As space is a limiting factor on reefs, corallimorpharians have developed various strategies for competition including the ability to kill corals, to reproduce asexually and to move across the substratum (7-18).

Depending on water quality and other environmental factors, the distribution of corallimorpharians within a reef may vary. They are known to withstand harsh conditions such as being exposed to air during low tides, which can give them an advantage in shallow waters (10). In addition, corallimorpharians have been reported to be able to proliferate in areas with high nutrient loads and plankton populations while corals generally prefer clear water (19-23). Further, Spiegel (24) noticed that high nutrient loads had a positive effect on corallimorpharians reproduction while such changes in water content may reduce coral growth $(25,26)$. Thus, conditions that may be unfavorable to other reef organism $<$ : may favor the corallimorpharians. In addition, corallimorpharians are efficient in establishing themselves on shallow reefs degraded by destructive fishing or other disturbances. Consequently, they may effectively prevent coral settlement $(10,16$, 17), and competitively exclude reef-building corals, especially those in the families Acroporidae, Pocillo
Figure 1. Map of the study area.

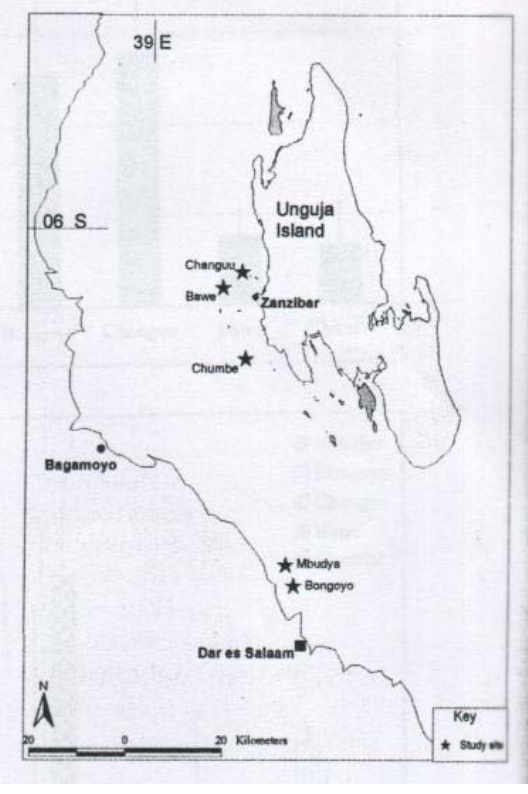

poridae and Poritidae $(13,27)$. As corallimorpharians are able to withstand various disturbances that influence the reef environment, human disturbances could work in their favor.

Since 1996, the abundance of corallimorpharians appears to have increased on coral reefs in Tanzania (28). This could be the result of increased human disturbances from, e.g. sewage loads and fishing activities. The 1998 coral bleaching event in the region (29-32) further disturbed reefs as it resulted in massive coral mortality, possibly favorable to the distribution of corallimorpharians. Not only did it open up space, but corallimorpharians may also be more resistant to increased temperatures (24), which was the primary cause of the coral bleaching event 1998 (31).

The aim of this study was to examine how the distribution and abundance of corallimorpharians in Tanzania is influenced by habitat characteristics and environmental disturbance.

\section{MATERIALS AND METHODS}

\section{Study Sites}

The study was conducted in October and November 1999 on 5 coral reefs in Tanzania that were influenced by disturbance to varying degrees $(28,33-36)$ (Fig. 1). All sites were located on patch or island reefs, which generally experience calm sea conditions. Three reefs were at Zanzibar Island, Unguja, while 2 reefs were near the mainland coast close to Dar es Salaam. The reefs at Zanzibar Island were situated at various distances from Zanzibar Town. The Changuu reef was closest to Zanzibar Town $(6 \mathrm{~km})$ and received a higher nutrient load than the other reefs at Zanzibar $(26,28,37,38)$. The Bawe reef was $7 \mathrm{~km}$ away from town, and did not receive the same high concentrations of nutrients as Changuu. Both these reefs were fished, which was not the case for the third reef examined at Zanzibar, the Chumbe reef, which is a marine protected area $13 \mathrm{~km}$ south of Zanzibar Town (Chumbe Island Coral Park: CHICOP) (33, $35,36)$. The study sites near the city of Dar es Salaam were the Bongoyo and Mbudya reefs. The Bongoyo reef is nearer the city (6 $\mathrm{km})$ than the Mbudya reef $(10 \mathrm{~km})$. The sewage and other wastes from 


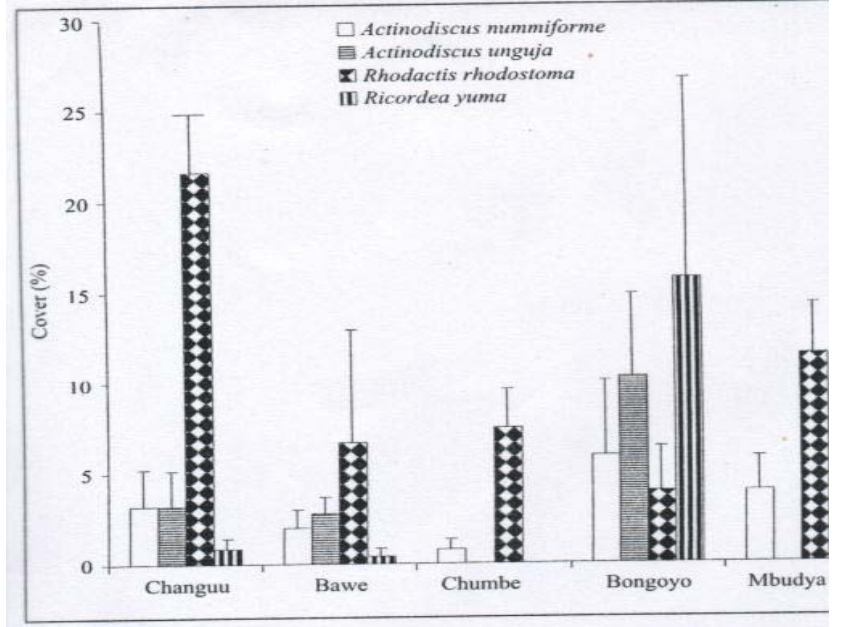

Figure 2. Percentage cover of the 4 common corallimorpharian species at each site.

Figure 2. Percentage cover of the 4 common corallimorpharian species at each site.

the city of Dar es Salaam are carried towards these reefs by the predominantly northward East African coastal currents and hence result in increasing nutrient pollution levels (39). The reefs are also influenced by sedimentation from rivers. Furthermore, these reefs are important tourist and fishing sites, and thus affected by motor boat traffic (40).

\section{Field Methods}

The abundance and distribution of corallimorpharians, scleractinian corals, and other benthic organisms were assessed using a combination of the line intercept transect technique (41) and the line intercept point method $(33,34,42)$. At each study site,

five $20-\mathrm{m}$ long transects were deployed horizontally in each of the following 5 reef zones: the inner reef flat; the middle reef flat; the outer reef crest; and at the 2 and $4 \mathrm{~m}$ depths on the outer reef slope. Along each $20-\mathrm{m}$ line transects points were randomly selected and a 2-m lineintercept transect (I $\mathrm{m}$ on each side) was set perpendicularly. Thus, a total of $10 \mathrm{~m}$ was examined within each $20-\mathrm{m}$ long transect. The types of living organisms and substrates observed to be in contact with corallimorpharians along the transects were recorded, according to categories in English et al (41). Species of corals were identified according to the method by Veron (43). Corallimorpharian species were identified at the Natural History Museum of Leiden, The Netherlands, in consultation with J.C. den Hartog.

Water visibility was estimated at each site using a Secchi disk (41). The level of sediment resuspension was classified as high when the substrate at the base of the reef was composed of silt (fine and easily resuspended particles), and as low when the

substrate was composed of nonresuspendable sand particles. A medium class was a mixture of the 2 particle sizes.

\section{Data Analyses}

The differences in corallimorpharians cover among reefs were analyzed using the I-way ANOV A and the Student-Newman Keuls test (SNK) (44). Assumptions of ANOV A were met in terms of normality and homogeneity of variances. The latter was confirmed using the Cochran's $C$ test ( $p>0,05)$. The Friedmans test was used to compare differences among reef habitats. The habitat preference by corallimorpharians was evaluated using the Strauss (45) selectivity index (L) and the Spearman rank order correlation (46) was used to establish the relationship between corallimorpharian abundance and water clarity.
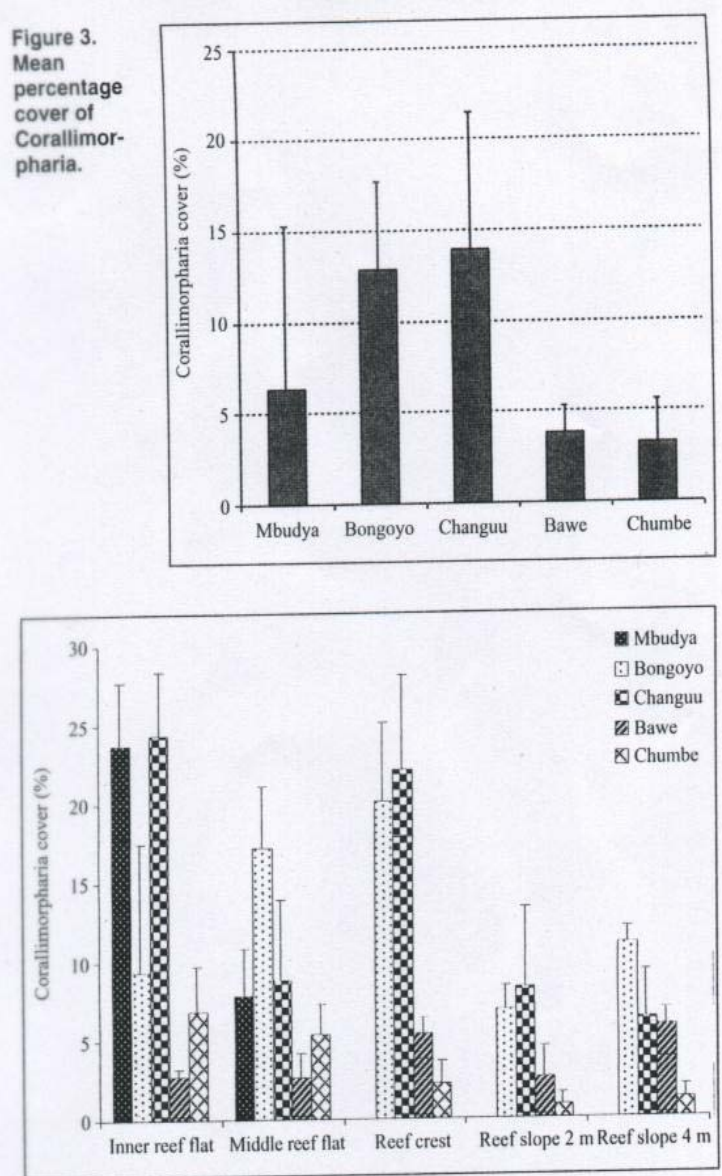

Figure 4. Percentage cover of Corallimorpharia at different depth levels at each site.

\section{RESULTS}

Corallimorpharians occurred on all the reefs. Five species were identified: Rhodactis rhodostoma, R. mussoides, Ricordea yuma, Actinodiscus unguja and A. nummiforme. All of them occurred at the Changuu, Bawe, and Bongoyo reefs. On the Bongoyo reef, all of the species made a relatively high contribution to the cover (Fig. 2). The number of species at Chumbe and Mbudya were limited to 2 (A. nummforme and $R$. rhodostoma). $R$. rhodostoma was the dominant corallimorpharian at all sites $(3.4 \%$ on reef slope; $10.9 \%$ on reef flat).

The cover of corallimorpharians varied significantly among reefs $(\operatorname{ANOV~A~F~}(4,128)=2.92, \mathrm{P}<0.05)$ and it was found that the Bongoyo and Changuu reefs had a significantly higher percent cover of corallimorpharians than the Bawe and Chumbe reefs (SNK test; Fig. 3). The Mbudya site did not differ significantly from any other site (SNK test; Fig. 3). The corallimorpharians were not uniformly distributed among the reef habitats surveyed (Friedman's test, $\mathrm{X}^{2} \mathrm{r}=9.25, \mathrm{OF}=4, \mathrm{P}<0.05$ ). A higher percent cover of corallimorpharians was observed on the reef crest and reef flat than on the reef slope at the 2-m and 4-m depths (Fig. 4). While $R$. rhodostoma occurred in all habitats examined, $A$. nummiforme was observed mostly on the reef slope. A. unguja was distributed from the reef crest to the reef slope and $R$. yuma on the flat.

The benthic category with the highest percent cover at all reef sites was the scleractinian corals, followed by the nonliving substrata (i.e. rock, rubble, and sand), dead coral, Corallimorpharia 
and algae (Fig. 5). Other benthic categories (e.g. soft corals and sponges) covered less than I \% of the substratum. Corallimorpharians ranked second, after stony coral, in percent cover of live benthic forms.

Corallimorpharians were found growing on or in contact with dead coral, rock, live scleractinian corals, dead coral, rubble, and soft coral. Scleractinian coral species that were in 111 esenterial contact with corallimorpharians included Acropora spp., Porites annae, $P$. cylindrica, P. lobata, P. lutea, P. nigrescens and PaVOfla spp. The corallimorpharians were not in contact with all benthic categories with equal frequency (Friedman test: $(\mathrm{x} 2 \mathrm{r}=9.25 ; \mathrm{DF}=4 ; \mathrm{P}<$ $0.0001 »$. Corallimorpharian contacts were not proportional to the relative abundance of the benthic category types. The Strauss (1979) selectivity index (L) indicated that

corallimorpharians prelcrred inhabiting dead coral $(\mathrm{L} 0.1 \mathrm{H})$ and rock and rubble combincd $(\mathrm{L}=0.14)$, whilst live coral was either avoided or not present $(\mathrm{L}=-0.27$ ) (Table 2$)$. The percent cover of corallimorpharians was significantly negative correlated with water clarity (Spearman Rank correlation: I' $=-0.9, \mathrm{P}<$ 0.05; Table I).

\section{DISCUSSION}

This study examined the composition of corallimorpharian communities on 5 coral reefs in Tanzania influenced by different degrees and types of disturbance. Corallimorpharians occurred on all reefs with a total of 5 species encountered. Overall they were the second most dominant living cover following stony corals. However, their cover varied among reefs with the highest densities on the more disturbed reefs in turbid nutrient-rich waters.

The reefs within the marine sanctuary had the lowest cover of Corallimorpharia and together with the Bawe reef, the clear

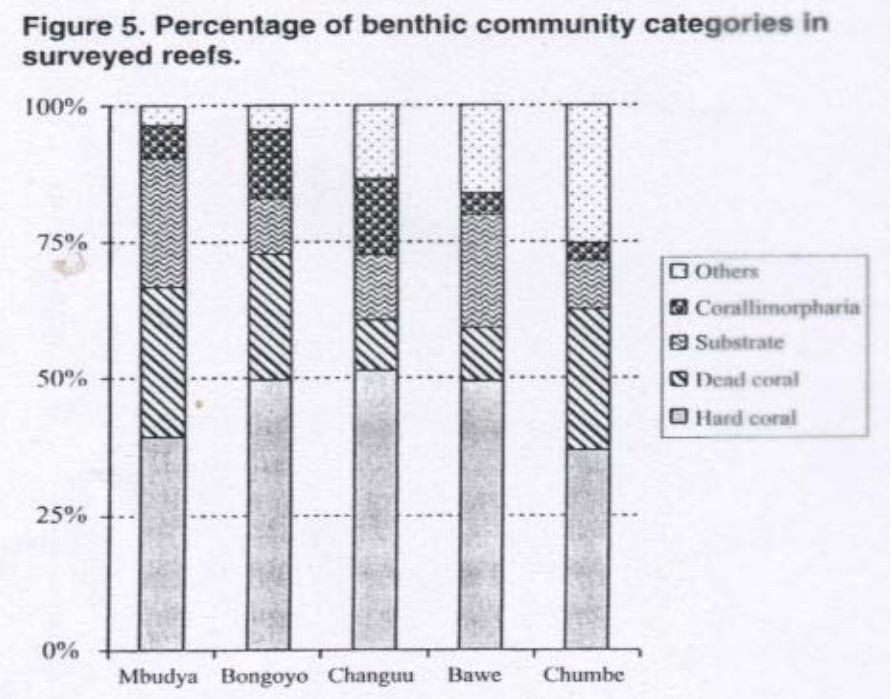

Table 2. Proportions of corallimorpharians in contact with benthic categories $(R)$, the relative contribution of the benthic categories (all sites pooled) (P), and the Strauss (45) Linear selectivity index (L). NB: Selectivity index (L) values range from -1 to 1 , with positive values indicating preference and negative values indicating avoidance or inaccessible;

Dead coral = dead coral + dead coral with algae; ns = L not significant from $0 ;{ }^{*}=$ significant; $* *$ very significant.

\begin{tabular}{lccrl} 
& $\mathrm{R}$ & $\mathrm{P}$ & $\mathrm{L}=\mathrm{R}-\mathrm{P}$ & $\mathrm{L}=0$ \\
\hline Hard coral & 0.184 & 0.455 & -0.271 & $\cdots$ \\
Dead coral & 0.372 & 0.189 & 0.183 & $*$ \\
Rock and rubble & 0.339 & 0.203 & 0.136 & $*$ \\
Algae & 0.004 & 0.045 & -0.041 & $\mathrm{~ns}$ \\
Soft coral & 0.100 & 0.005 & 0.095 & $\mathrm{~ns}$ \\
Sponges & 0.000 & 0.008 & -0.008 & $\mathrm{~ns}$ \\
Others & 0.000 & 0.014 & -0.014 & ns \\
\hline
\end{tabular}

est waters. The 2 reefs with the highest abundances of corallimorpharians, the Bongoyo and Changuu reefs, had the lowest visibility and the highest readings of sediment resuspension. At Bongoyo, the poor visibility was caused by the vicinity to Dar es Salaam and its sewage effluents, the river input from the adjacent seasonal rivers as well as the frequent passage of motorboats near the reef. At Changuu, the suspended solids originated from land sources, especially the Zanzibar municipal sewage discharge system, which also increased the nutrient load $(26,28,37,38)$. Opposite to corallimorpharians, turbidity and enhanced nutrient loads are generally stressful to stony corals, which may give corallimorpharians a competitive advantage, (19-21, 47, 4R).

In addition to showing high tolerance to turbidity, coral limorpharians have been noted to withstand higher temperatures (24). There arc indications that the corallimorpharians have increased in abundance in Tanzania over the last few years (28). Long-term trends from other studies suggest that the abundance of corallimorpharians may increase with time as reef degradation continues $(17,24)$. In Tanzania, an important factor, influencing corallimorpharian densities, could be the 1998 coral bleaching event, which was induced by extraordinarily high temperatures that resulted in large-scale coral mortality (29-32).

The distribution of the corallimorpharians within the reefs further indicates that they are successful in withstanding conditions that could be stressful to corals. The highest cover of corallimorpharians was found on the shallow reef flat and reef crest. Similar results have been observed in other studies $(10,16)$. The reef flat areas are particularly susceptible to natural disturbances such as exposure to air and direct sunlight as well as a range of human impacts including sewage outlets (19-21) and artisanal fishing $(35,49,50)$. Disturbance on coral reefs opens up space and corallimorpharians may be successful in competing for such areas. In this study, they preferred inhabiting flattened dead coral and rock and rubble combined. In other studies, they have also been noted to grow on dead coral and rock by forming large aggregations that hinder the recruitment of stony corals (10). Indeed, the corallimorpharians have developed mechanisms to occupy such areas, including the formation of large colonies of polyps sustained by asexual reproduction through fission and budding $(10,14,15,28,51)$.

Obviously, corallimorpharians seem to have competitive advantages over many other benthic sessile organisms in being able to proliferate in environments that diverge from average conditions. In addition, they can also be strong competitors in the battle for space by direct agonistic suppression. In this study, corallimorpharians were observed to be in direct contact with living coral colonies. Closer observations showed that colonies of Porites spp. and Acropora spp. that were in contact with corallimorpharians had their contact edges bleached implying that they were stressed. Studies elsewhere have shown that corallimorpharians tend to negatively affect scleractinian coral (27), sometimes by overgrowing and killing them. They use marginal tentacles with powerful nematocysts $(13,16,27)$, and may also employ mesenterial filaments, which secrete digestive enzymes $(11,13,17,18$, 48). Among the species of corallimorpharians encountered in this study, Rhodactis rhodostoma

\begin{tabular}{|c|c|c|c|}
\hline Site & $\begin{array}{l}\text { Secchi disk } \\
(m)\end{array}$ & $\begin{array}{l}\text { Sediment } \\
\text { resuspension }\end{array}$ & $\begin{array}{l}\text { Corallimorpharia } \\
\text { (\%) cover }\end{array}$ \\
\hline $\begin{array}{l}\text { Changuu } \\
\text { Bawe } \\
\text { Chumbe } \\
\text { Bongoyo } \\
\text { Mbudya }\end{array}$ & $\begin{array}{r}3.3 \\
10.5 \\
10.5 \\
3.0 \\
4.8\end{array}$ & $\begin{array}{l}\text { High } \\
\text { Low } \\
\text { Low } \\
\text { High } \\
\text { Medium }\end{array}$ & $\begin{array}{r}14.0 \\
3.8 \\
3.3 \\
12.9 \\
6.3\end{array}$ \\
\hline
\end{tabular}

was abundant on all surveyed reefs. This species is known to possess powerful mechanisms for the monopolization of space (52). Traits such as the capacity to reproduce asexually, to be mobile (24) and to damage neighboring organisms (16, 27) are successful strategies in the struggle for space (12).

In conclusion. results from this 
study suggest that corallimorpharians may have competitive advantages in water conditions that are stressful to corals. One factor that seemed to be an important determinant in coralli morpharian presence was water turbidity and nutrient content. There are also reasons to believe that the 1998 coral bleaching event had a positive effect on the populations of corallimorpharians. Reefs with high densities of corallimorpharians were also affected by other disturbances such as fishing. In addition, the corallimorpharians were strong aggressors in the struggle for space by attacking corals. Thus, their abilities to proliferate in poor water conditions and their capacity to occupy substratum opened up by physical disturbance as well as their aggressive behavior can make corallimorpharians successful on disturbed coral reefs.

\section{References and Notes}

1. Carlgren, O. 1949. A survey of the Ptychodactiaria, Corallimorpharia and Actiniaria. Kungl. Svenska Vetensk. Akad. Handl. 1,14-16.

2. Schmidt, 11. 1974. On evolution in the Anthozoa. Proc. $2^{\text {nd }}$ Intl. Coral Reef Symp. Australia. 2, 533-560.

3. den Hartog, J.C. 1980. Caribbean shallow water Corallimorpharia. Zool. Verhand. 176, $1-82$.

4. Pinto, S.M., da Costa Belem, M.J. 2000. Cnidae of two species of Discosomatidae (Cnidaria, Anthozoa, Corallimorpharia) from Brazil. Proc. Biol. Soc. Wash. 113, 129 144 .

5. Benayahu, Y. and Loya, Y. 1981. Competition for space among coral reef sessile or ganisms at Eilat, Red Sea. Bull. Mar. Sci. 31,514-522.

6. Sheppard, C.R.c. 1982. Coral populations on reef slopes and their major controls. Mar Ecol. Prog. Ser. 7,83-115.

7. Chadwick, N.E. 1991. Spatial distribution and the effect of competition on some tem perate scleractinia and corallimorpharia. Mar. Ecol. Prog. Ser. 70,39-48.

8. Ridzwan, A.R. 1993. Recovery Processes of Coral Communities Following the Crown of-Thorns Starfish, Acanthaster planci, Infestations all the East Coast Islands of Peninsular Malaysia. Ph.D. dissertation, Newcastle University, United Kingdom. 303 pp.

9. Gerald, R.A. and Roger, S. 1994. Indo-Pacific Coral Reef Field Guide. Tropical Reef Research, Calendar Print Pte Ltd, Singapore, $253 \mathrm{pp}$

10. Chadwick-Furman, N.E. and Spiegel, M. 2000. Abundance and clonal replication of the tropical corallimorpharian Rhodactis rhodostoma. Invertebr. Biol. 119,351-360.

11. Chadwick, N.E. 1987. Interspecific aggressive behaviour of the corallimorpharian Corynactis californica (Cnidaria: Anthozoa): Effects on sympatric corals and sea anemo nes. Bioi Bull./173, 110-125.

12. Chadwick, N.E. and Adams, C. 1991. Locomotion, ascxual reproduction and the kill ing of corals by the corallimorpharian Corynactis californica. Hydrobiologia 216, 263 269.

13. Miles, J.S. 1991. Inducible agonistic structures in the tropical corallimorpharian, Discosoma sanctithomae. Bioi. Bull. 18O, 406-415.

14. Chen Chao-Lun, A., Chen Chang-Po and Chen I-Mingo 1995. Sexual and asexual re production of the tropical corallimorpharian Rhodactis (= Discosoma) indosinensis (Cnidaria: Corallimorpharia) in Taiwan. Zool. Stud. 34, 29-40.

15. Chen Chao-Lun, A., Chen Chang-Po and Chen I-Mingo 1995. Spatial variability of size and sex in the tropical corallimorpharian Rhodactis indosinensis (Cnidaria: Coralli morpharia). Zool. Stud. 34, 82-87.

16. Langmead, O. and Chadwick-Furman, N.E. 1999. Marginal tentacles of the corallimorpharian Rhodactis rhodostoma 1. Role in competition for space. Mar. Biol. 134,479-489.

17. Langmead, O. and Chadwick-Funnan, N.E. 1999. Marginal tentacles of the coralli morpharian Rhodactis rhodostoma. 2. Induced development and long-term effects on coral competitors. Mar. Biol. 134,491-500.

18. Rossi. S. and Snyder, M.J. 2001. Competition for space among sessile marine inverte brates: Changes in HSP70 expression in two Pacific cnidarians. Biol. Bull. 201,385 393

19. Pastorak, R.A. and Bilyard, G.R. 1985. Effects of sewage pollution on coral-reef com munities. Mar. ECol. Prog. Ser. 21, 175-189.

20. Rogers, C.S. 1990. Responses of coral reefs and reef organisms to sedimentation. Mar. Ecol. Prog. Ser. 62, 185-202.

21. Willenberg, M. and Hunte, W. 1992. Effects of eutrophication and scdimentation on juvenile corals. I. Abundance, mortality and community structure. Mar. Biol. 116, 131 138.

22. Rajasuriya, A., Ohman, M.C. and Johnstone, R. W. 1998. Coral and sandstone reef habitats in north-western Sri Lanka: patterns in the distribution of coral communities. Hydrobiologia 3._2, 31-43.

23. Rajasuriya, A., Ohman, M.C. and Svensson, S. 1998. Coral and rock reef-habitats in southern Sri Lanka; patterns in the distribution of coral communities. Ambio 27, 723 728.

24. Spiegel, M. 1998. Sexual and Asexual Reproduction in the Tropical Corallimorpharian Discosoma (Rhodactis) rhodostoma in the Northern Red Sea. MSc Thesis, Bar-llan University, Israel.

25. Kinsey, D.W. and Davies, P.J. 1979. Effect of elevated Nitrogen and phosphorous levels on coral reef growth. Limnol. Oceanogr. 24,935-940.

26. Bjork, ,M., Mohammed, S.M., Bjorklund, M. and Semesi, A. 1995. Coralline algae, important coral-reef builders threatened by pollution. Ambio 24, 502-505.

27. den Hartog, J.C. 1977. The marginal tentacles of Rhodactis sanetithomae (Coralli morpharia) and the sweeper tentacles of Montastrea cavemosa (Scleractinia); their cnidom and possible function. Proc. 3rd lnt. Coral Reef Symp. Miami, 1,463-469.

28. Kuguru, B.L. 2002. The Distribution and Abundance of Rhodaetis spp. (Cnidaria: Corallimorpharia) and Their Competitive Effects on Stony Corals (Cnidaria: Scleractillia) all Selected Reefs Around Zanzibar. MSc. Thesis, University of Dar es salaam, Tanzania.

29. Muhando, C. 1999. Assessment of the extent of damage, socio-economics, mitigation and recovery in Tanzania. In: Coral reef degradation in Indian Ocean States Reports and Project Presentations. Linden, O. and Sporrong, N. (eds). CORDIO, Stockholm, pp. 43-47.

30. Ohman, M.C., Lindahl, U. and Schelten, C.K. 1999. Influence of coral bleaching on the the fauna of Tutia Reef, Tanzania. In: Coral Reef Degradation in the Indian Ocean. Linden, $\mathrm{O}$. and Sporrong, N. (eds). CORDIO, Stockholm. pp. 48-52.

31. Lindahl, U., Ohman, M.C. and Schelten, C.K. 2001. The 1997/1 98 mass mortality of corals: effects on fish communities on a Tanzanian coral reef. Mar. Pollut. Bull. 42, 127131.

32. Garpe, K.C. and Ohman, M.C. Coral and fish distribution patterns in Mafia Island Ma rine Park, Tanzania: fish-habitat interactions. Hydrohiologia. (In press).

33. Bergman, K.C. and Ohmall, M.C. 2001. Coral reef structure at Zanzibar Island. Proc. Conf. Adv. Mar. Sci. Tanzania. IMS, UDSM, Tanzania, pp. 263-275.

34. Bergman, K., Ohman, M.C. and Svensson, S. 2000. Influence of habitat structure on the abundance of Pomacentrus sulfureus, a western Indian Ocean reef-fish. Env. Biol. Fish $59,243-252$.

35. McCianahall, T.R. and Arthur, R. 2001. The effect of marine reserves and habitat on populations of East African coral reef fishes. Ecol. Appl. 11, 559- 569

36. Mbije, N.E., Wagner, G.M., Francis, J., Obman, M.C. and Bergman, K.C. 2002. Pat terns in the distribution and abundance of hard corals around Zanzibar Island. Ambio 31, 609-6 I I .

37. Mohammed, M.S. and Mgaya, Y.D. 2001. Nutrient levels and their dynamics in the coral reefs off Zanzibar Town. Proc Conf Adv. Mar. Sci. Tanzania. IMS, UDSM, Tanzania, pp. 171183.

38. Kangwe, J.W. 1999. The Effect of Land-hosed Pollution on the Reef Building Caleareolls Algae in the Reefs near Zanzibar Town. MSc, Thesis. University of Dar es Salaam, Tanzania. 107 pp.

39. Newell, B.S. 1957. A preliminary survey of hydrography of the British East African coastal waters. Fishery Publ. Colon. Off No.9. 21 pp.

40. Muhando, C.A. and Francis, J. 2000. The States of Coral Reefs in the Dar es Salaam Marine Reserves System and the State of Reefs in Other Marine Protected Areas of Tanzania. IMS/UNEP/ICLAN Report. 32 pp.

41. English, S., Wilkinson, C. and Baker, V. 1994. Survey Manual for Tropical Marine Resources. Australian Institute of Marine Science, Townsville, $117 \mathrm{pp}$.

42. Wiens, J.A. and Rotenberry, J.T. 198 I. Habitat associations and community structure of birds in Shrub steppe environments. Ecol. Monogr. 51, 409-422.

43. Veron, J.E.N. 1986. Corals of Australia and the Indo-Pacific. University of Hawaii Press. 490 pp.

44. Sokal, R.R. and Rohlf, F.J. 1995- Biometry. Freeman, New York

45. Strauss, R.E. 1979. Reliability estimates for Ivlev's electivity index, the forage ratio, and a proposed linear index of food selection. Trans. Amer. Fish. Soc. 108,344-352.

46. Conover, W.J. I_80. Practical Nonparametric Statistics. John Wiley \& Sons, New York.

47. Rogers, C.S. 1979. The effect of shading on coral reef structure and function. J. Exp. Mar. Biol. Ecol. 41,269-288.

48. Hamuer, W.M. and Dunn, D.F. 1980. Tropical Corallill1orpharia (Coelcllterata: Anthozoa): feeding by envelopment. Micronesica 16, 37-41.

49. Russ, G.R. and Aleala, A.C. 1989. Effects of intense fishing pressure on an assem blage of coral reef fishes. Mar. Ecol. Prog. Ser. 56,13-27.

50. Ohman, M.C., Rajasuriya, A. and 6lafsson, E. 1_97. Reef fish assemblages in north western Sri Lanka: distribution patterns and influences of fishing practises. Env. Biol. Fish. 49,45-61.

51. Chadwick-Furman, N.E., Nir, I. and Spiegel, M. 2000. Sexual reproduction in the tropi cal corallimorpharian Rhodactis rhodostoma. Invertebr. Biol. 119, 361-369.

52. Jackson, J.B.C. 1977. Competition on marine hard substrate: the adaptive significance of solitary and colonial strategies. Am. Not. 111,743-767.

53. This study was supported by CORDIO (the Coral Reef Degradation in the Indian Ocean project) and the Sida/SAREC Bilateral Marine Science Programme between Sweden and Tanzania for research in marine zoology (Sida = Swedish International Development and Cooperation Agency). We appreciate the field assistance provided by E. Evans, M.N. Mohammed and J. Katomanga. The Director of the Institute of Marine Sciences in Zanzibar provided SCUBA equipment used in the surveys. Logistical support was also given by the Department of Zoology and Marine Biology, University of

Dar es Salaam, as well as the Kunduchi Fisheries Institute. We also acknowledge J.C. den Hartog for advice in identifying corallimorpharian species and K. Bergman, N.E Chadwick-Furman, M. Gullstrom and M.D. Richmond for comments on the manuscript.

Christopher A. Muhando, is a PhD candidate at the University of Dar es Salaam, Tanzania. His research interests are in coral reef ecology, coral larvae settlement dynamics, reef restoration and coastal resource mapping using GIS techniques. His address: Institute of Marine Sciences, University of Dar-es-Salaam, P.O. Box 668, Zanzibar, Tanzania. E-mail: muhando@ims.udsm.ac.tz

Baraka L. Kuguru, MSc, is a research assistant at the Inst. of Marine

Science, University of Dar es Salaam. His research interests are in the ecology of corallimorpharians. His address: Institute of Marine Sciences, University of Dar-es-Salaam, P.O. Box 668, Zanzibar, Tanzania. E-mail: muhando@ims.udsm.ac.tz

E-mail: barakakuguru@hotmail.com

Gregory M. Wagner, PhD, is a senior lecturer at the Department of Zoology and Marine Biology, University of Dar es Salaam, Tanzania carrying out research in coral reef and mangrove ecology and restoration. He is also the theme leader for coral reefs in the Science and Technical Working Group (STWG) of Tanzania Coastal Management Partnership (TCMP). His address: Department of Zoology and Marine Biology, University of Dar es Salaam, P.O. Box 35064,

Dar es Salaam, Tanzania.

E-mail: gwagner@udsm.ac.tz

Nsajigwa E. Mbije, is a PhD candidate at the University of Oar es Salaam, Tanzania. His research Interests are in aquaculture and coral reef ecology.
His address: Institute of Marine Sciences, University of Dar-es-Salaam, P.O.

Box 668, Zanzibar, Tanzania.

E-mail: mbije@zims.udsm.ac.tz

Marcus C. Ohman, PhD, is a research scientist and senior lecturer at the

Department of Zoology, Stockholm University. His research interests are in marine ecology, fisheries, disturbance effects on the marine biota, environmental economics and coastal zone management. He is coordinating and acting research advisor for various Sida supported projects in marine science. His address: Department of Zoology, Stockholm University, SE-106 91 Stockholm, Sweden. E-mail: marcus.ohman@zoologi.su.se 